Biochimica et Biophysica Acta, 428 (1976) 35-44

(C) Elsevier Scientific Publishing Company, Amsterdam - Printed in The Netherlands

BBA 27834

\title{
SEDIMENTATION BEHAVIOR OF SOLUBILIZED GONADOTROPIN RECEPTOR FROM PLASMA MEMBRANES OF BOVINE CORPUS LUTEUM
}

\author{
V. THAMBYRAJAH *, SALMAN AZHAR ** and K.M.J. MENON *** \\ Endocrine Laboratory, Departments of Obstetrics and Gynecology and Biological \\ Chemistry, The University of Michigan Medical Center, Ann Arbor, Mich. 48104 (U.S.A.) \\ (Received September 12th, 1975)
}

\section{Summary}

The gonadotropin receptors associated with plasma membrane fractions were solubilized by detergents, including Triton X-100, Lubrol WX, Lubrol PX and sodium deoxycholate before and after equilibration with ${ }^{125}$ I-labelled human chorionic gonadotropin. The binding activity remained in solution even after centrifugation at $300000 \times g$ for $3 \mathrm{~h}$. The solubilized gonadotropin receptor or gonadotropin receptor complex was characterized by gel filtration and sucrose density gradient centrifugation. Sucrose density gradient centrifugation of solubilized gonadotropin-receptor complex in the presence of Triton X-100 had a sedimentation coefficient of $6.5 \mathrm{~S}$ whereas the solubilized uncomplexed receptor had a sedimentation coefficient of $5.1 \mathrm{~S}$. In the absence of the detergent, solubilized hormone receptor complex from plasma membrane fractions I and II sedimented with an apparent sedimentation coefficient of $6.6 \mathrm{~S}$ and $7.4 \mathrm{~S}$, respectively. Similarly, the free receptor also showed higher sedimentation profile with an apparent sedimentation coefficient of $6.7 \mathrm{~S}$ for fraction I and $7.2 \mathrm{~S}$ for fraction II. Treatment of plasma membranes with phospholipase A and $\mathrm{C}$ inhibited the binding of ${ }^{125} \mathrm{I}$-labelled human chorionic gonadotropin in a dose dependent manner, whereas phospholipase $\mathrm{D}$ was without any effect. Doses of $1.4 \mathrm{mI} . \mathrm{U}$. of phospholipase $\mathrm{A}$ or $0.6 \mathrm{mI}$.U. of phospholipase $\mathrm{C}$ were required to produce $50 \%$ inhibition of the binding activity. These phospholipases had no effect on the preformed ${ }^{125}$ I-labelled human chorionic gonadotropin-receptor complex nor on the sedimentation profile of solubilized gonadotropin receptor complex.

* Visiting Scientist. Present address: Dept. of Biochemistry, Faculty of Medicine, University of Malaya, Kuala Lampur, Malysia.

** Population Council Postdoctoral Fellow.

*** To whom correspondence should be addressed. 


\section{Introduction}

The initial step in the action of luteinising hormone or human chorionic gonadotropin involve the binding of the hormone to its receptor on plasma membrane of the ovarian cell which results in the activation of adenylate cyclase $[1,2]$ and increased steroidogenesis $[3-6]$. Recently, several reports have appeared which describe the properties of the membrane receptors from ovarian preparations [ $7-13]$.

We have reported previously on the isolation of plasma membranes from bovine corpus luteum possessing gonadotropin sensitive adenylate cyclase and ${ }^{125}$ I-labelled gonadotropin binding activities [2]. In our continuing efforts to understand the mechanism of action of gonadotropin in the corpus luteum, we are investigating the properties of the isolated plasma membrane with respect to its various catalytic properties $[2,14-16]$. In this report we describe the sedimentation properties of the solubilized gonadotropin receptor from the plasma membranes of bovine corpus luteum.

\section{Materials and Methods}

Corpora lutea. Fresh bovine corpora lutea were obtained from a local slaughterhouse, placed in normal saline, transported to the laboratory in ice, and either processed immediately or frozen at $-80^{\circ} \mathrm{C}$ until further use.

Chemicals. Phospholipase A (Bee Venom) and phospholipase C (Clostridium welchii) were obtained from Sigma Chemical Co. ${ }^{125}$ I-labelled human chorionic gonadotropin was generously supplied by Dr. A. Rees Midgley, Jr. of this University. All other chemicals used were conventional commercial products.

Preparation of plasma membrane fraction from bovine corpus luteum. Plasma membrane fractions (fractions I and II) were prepared as described by Gospodarowicz [8]. Purity of plasma membranes was checked by assaying various marker enzymes $[8,14]$. These included $\mathrm{Na}^{+}, \mathrm{K}^{+}$and $\mathrm{Mg}^{2+}$ dependent ATPase, 5 '-nucleotidase and glucose-6-phosphatase by the method of Solyom and Trams [17], NADH cytochrome $C$ reductase by the procedure of Phillips and Langdon [18], succinic dehydrogenase by the method of Veeger et al. [19] and glucose-6-phosphate dehydrogenase according to Langdon [20].

Assay of ${ }^{125}$ I-labelled human chorionic gonadotropin binding to plasma membranes. The assay for specific binding of ${ }^{125}$ I-labelled gonadotropin to membranes was carried out as described earlier [2]. Membranes (100 $\mu \mathrm{g}$ protein) were incubated in $0.3 \mathrm{ml}$ of buffer $(10 \mathrm{mM}$ Tris-HCl buffer of $\mathrm{pH} 7.2$, $1 \mathrm{mM} \mathrm{CaCl} 2$ containing $0.1 \%$ bovine serum albumin) with ${ }^{125}$ I-labelled gonadotropin $(70000 \mathrm{cpm})$ at $37^{\circ} \mathrm{C}$ for $90 \mathrm{~min}$. Following incubation, $1 \mathrm{ml}$ of buffer was added to each tube and centrifuged at $10000 \times \mathrm{g}$ for $10 \mathrm{~min}$. The supernatants were discarded and sediments were again suspended in $1 \mathrm{ml}$ of buffer and centrifuged as above. The supernatant from second was were again discarded and the tubes were then counted in a Packard automatic gamma spectrometer. In each case specific binding of labelled gonadotropin was determined by subtracting from the total counts radioactivity associated with membrane fraction in the presence of 1000-fold excess of unlabelled gonadotropin [2]. 
Assay of ${ }^{125}$ I-labelled gonadotropin binding to Triton X-100* solubilized receptor. The ${ }^{125}$ I-labelled gonadotropin binding to solubilized receptor was carried out employing a double precipitation of the gonadotropin-receptor complex with polyethylene glycol as described by Dufau et al. [21] .

Solubilization of prelabelled plasma membranes. Aliquots of plasma membranes (100 $\mu \mathrm{g}$ protein) in Buffer A were incubated at $37^{\circ} \mathrm{C}$ for $90 \mathrm{~min}$ in the presence of $70000 \mathrm{cpm}$ of ${ }^{125}$ I-labelled gonadotropin, washed three times with $2 \mathrm{ml}$ of buffer to remove unbound hormone and the membranes were recovered by centrifugation at $20000 \times g$ for $15 \mathrm{~min}$. The prelabelled membranes were then extracted separately with various concentrations of Triton X-100, Lubrol $\mathrm{XW}^{*}$ and Lubrol $\mathrm{PX} *$ for $1 \mathrm{~h}$ at $4^{\circ} \mathrm{C}$. After detergent treatment the suspensions were centrifuged at $20000 \times g$ for $20 \mathrm{~min}$. The soluble fractions were then subjected to gel filtration on Sephadex G-200 columns and sucrose density gradient centrifugation. Centrifugation of the supernatant solution at $300000 \times g$ for $3 \mathrm{~h}$ was also carried out to determine if the radioacitivity associated with hormone receptor complex remained in the supernatant.

Solubilization of the free receptor. Plasma membranes were suspended in buffer containing $1 \%$ Triton X-100 and incubated at $4^{\circ} \mathrm{C}$ for $1 \mathrm{~h}$. After dilution of the detergent to $0.1 \%$ with buffer, the suspension was centrifuged at 27000 $X g$ for 20 min to remove the unsolubilized membrane. The solubilized binding fraction was not sedimented on further centrifugation at $300000 \times g$ for $3 \mathrm{~h}$.

Sucrose density gradient centrifugation. Sucrose density gradient centrifugation in 5 to $20 \%(\mathrm{~W} / \mathrm{V})$ sucrose with or without $0.1 \%$ Triton X-100 was performed as described by Martin and Ames [22] and Kuczenski [23]. Catalase $(11.6 \mathrm{~S})$, glyceraldehyde-3-phosphate dehydrogenase $(7.7 \mathrm{~S})$ and alcohol dehydrogenase (4.5 S) were used as internal markers [14].

Protein determinations. The protein content was determined by the method of Lowry et al. [24] using bovine serum albumin as standard.

\section{Results and Discussion}

Plasma membranes. The purity of plasma membranes were ascertained by assaying various plasma membrane marker enzymes that are specific for plasma membranes and other cellular organelles [17]. Relative to the $5^{\prime}$-nucleotidase the purification of plasma membrane fraction averaged 9-10 fold, a value similar to that reported by Gospodarowicz [8]. Contamination of the isolated plasma membranes by other cellular components was less than five percent as judged by assaying specific marker enzymes (see Materials and Methods).

Binding of ${ }^{125}$ I-labelled gonadotropin to bovine corpus luteum plasma membranes. Plasma membrane fractions I and II isolated from bovine corpus luteum showed specific binding of ${ }^{125}$ I-labelled human chorionic gonadotropin (Table I). Both fractions I and II showed comparable binding activities when assayed either separately or mixed together (Table I). In subsequent experiments, a mixture of fractions I and II were used for binding studies. Saturation of the binding of ${ }^{125} \mathrm{I}$-labelled gonadotropin to plasma membrane was achieved at a concentration of approximately $5 \cdot 10^{-9} \mathrm{M}$ to $1 \cdot 10^{-8} \mathrm{M}{ }^{125}$ I-labelled gonado-

* Triton X-100, octyl phenoxy polyethoxyethanol; Lubrol PX and Lubrol WX, polyoxyethylene alcohols. 
TABLE I

125I-LABELLED GONADOTROPIN BINDING TO PURIFIED PLASMA MEMBRANE FRACTION FROM BOVINE CORPUS LUTEUM

The incubation medium in a final volume of $0.3 \mathrm{ml}$ contained Tris $\cdot \mathrm{HCl}$ buffer, $\mathrm{pH} 7.2,3 \mu \mathrm{mol} ; \mathrm{CaCl}_{2} \mathbf{0 . 3}$ $\mu \mathrm{mol}$, bovine serum albumin $0.1 \%,{ }^{125}$ I-labelled gonadotropin $1 \mathrm{ng}\left(1.6 \times 10^{-10} \mathrm{M}\right), 100 \mu \mathrm{g}$ plasma membrane protein and where required, $3 \mu \mathrm{g}$ of unlabelled gonadotropin. After incubation at $37^{\circ} \mathrm{C}$ for $90 \mathrm{~min}$ the tubes were then processed for radioactivity as described under Materials and Methods.

\begin{tabular}{ll}
\hline Plasma membrane & $\begin{array}{l}125 \text { I-labelled gonadotropin bound } \\
\left(\mathrm{dpm} \times 10^{-3}\right) / \mathrm{mg} \text { membrane protein* }\end{array}$ \\
\hline Fraction I & $57.3 \pm 2.8$ \\
Fraction II & $68.2 \pm 3.2$ \\
Fractions I and II & $62.3 \pm 5.1$ \\
\hline
\end{tabular}

* Each value represents the mean \pm S.E. of three determinations.

tropin (Fig. 1). The binding activity increased with increasing concentrations of membrane protein, reaching saturation at about $250 \mu \mathrm{g}$ in the presence of a fixed amount of ${ }^{125} \mathrm{I}$-labelled gonadotropin $\left(1.6 \cdot 10^{-10} \mathrm{M}\right)$. Specific binding of ${ }^{125}$ I-labelled gonadotropin to plasma membranes was also dependent on incubation time and temperature. The general properties of the binding of ${ }^{125} \mathrm{I}$ labelled gonadotropin to plasma membranes are comparable to those described earlier [7-13].

Solubilization of bovine corpus luteum plasma membranes pre-labelled with ${ }^{125}$ I-labelled gonadotropin by detergents. Extraction of the preformed ${ }^{125} \mathrm{I}$ labelled gonadotropin-receptor complex was attempted with Lubrol WX, Lubrol PX and Triton X-100. Triton X-100 was found to be a better solubilizing agent as compared to other detergents. Almost $50 \%$ of hormone receptor complex was solubilized by Triton X-100 (Fig. 2) at a concentration of $0.5 \%$. Lubrol WX and Lubrol PX solubilized $30-40 \%$ of the prelabelled hormone receptor complex at the concentration range of 0.1 to $1 \%$. Ionic detergents such a sodium deoxycholate also solubilized the hormone-receptor complex, but was not as effective as Triton X-100. Preliminary experiments using a solu-

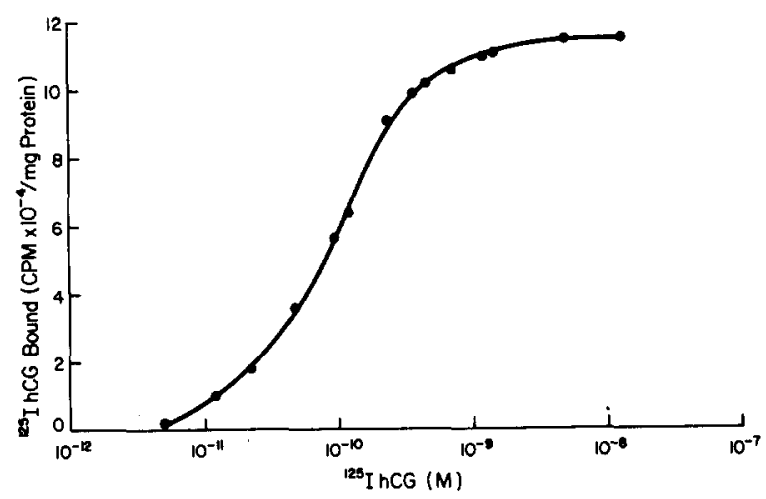

Fig. 1. Binding of 125 I-labelled gonadotropin to bovine corpus luteum plasma membranes as a function of the concentration of labelled hormone. Plasma membranes (100 $\mu \mathrm{g}$ of protein) were incubated for $90 \mathrm{~min}$ with increasing amounts of 125 r-labelled gonadotropin in Buffer A $(10 \mathrm{mM}$ Tris- $\mathrm{HCl}, \mathrm{pH} 7.5$, containing $1 \mathrm{mM} \mathrm{CaCl}_{2}$ and $0.1 \%$ bovine serum albumin). Other details were similar to that described in the text. 


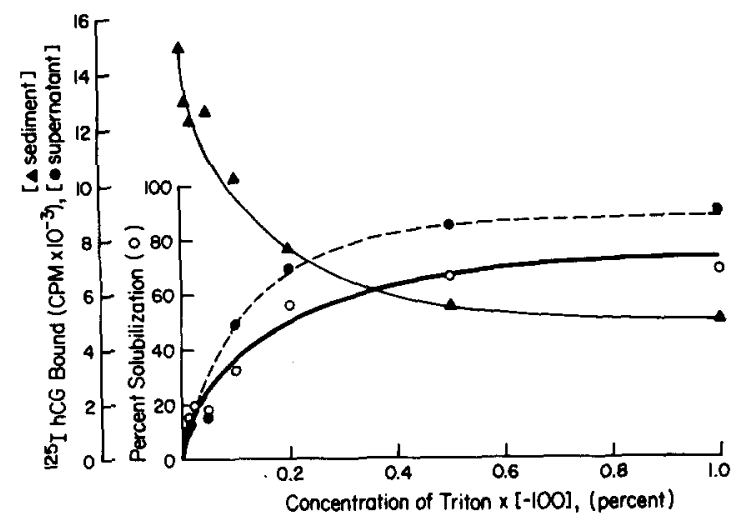

Fig. 2. Solubilization of prelabelled 125 I-labelled gonadotropin-receptor complex of bovine corpus luteum with increasing concentration of Triton X-100. Expeximental details were similar to that described in the text.
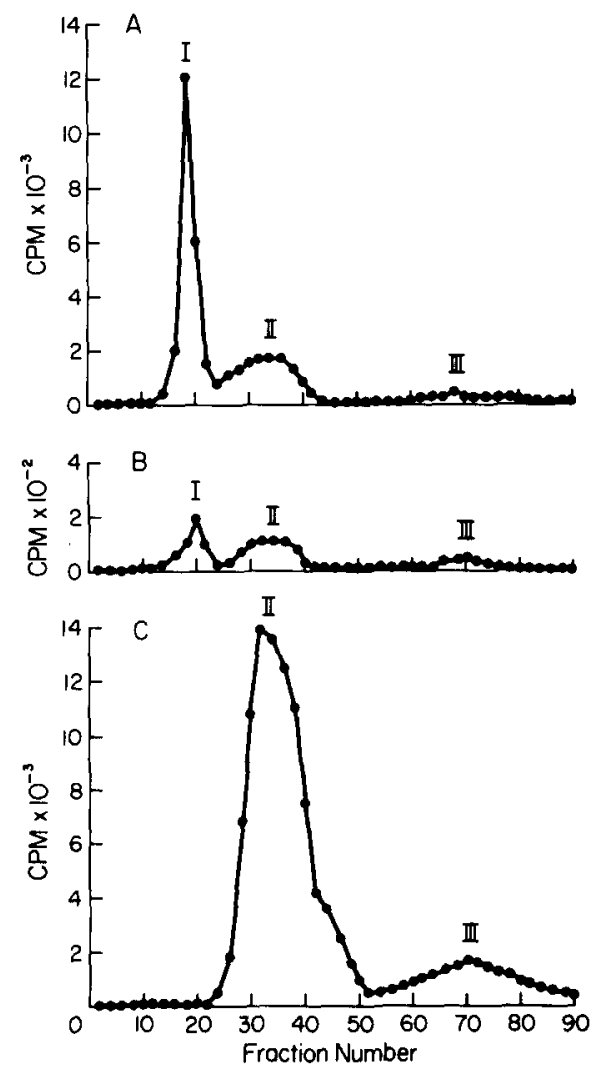

Fig. 3. Filtration of 125 I-labelled gonadotropin-receptor complex through sephadex G-200 column. After prelabelling of membranes with 125 I-labelled gonadotropin, the hormone receptor complex was solubilized by Triton X-100 (0.4\%). The solubilized complex was filtered through Sephadex G-200 column $(2.5 \times 40 \mathrm{~cm})$ equilibrated with $10 \mathrm{mM}$ Tris-HCl pH 7.2 containing $1 \mathrm{mM} \mathrm{CaCl}, 0.1 \%$ bovine serum albumin and $0.1 \%$ Triton $X-100$. 3-ml fractions were collected and radioactivity was then determined in each fraction. (A) 125 I-labelled gonadotropin-receptor complex; (B) ${ }^{125}$ I-labelled gonadotropin-receptor complex preincubated in the presence of excess unlabelled gonadotropin $\left(1 \cdot 10^{-7} \mathrm{M}\right) ;(\mathrm{C})$ Free $125_{\mathrm{I}}$ labelled gonadotropin. 
tion of high ionic strength failed to solubilize either the free receptor or hormone receptor complex. Only detergent treatment described above could solubilize both the free receptor as well as hormone receptor complex.

Gel filtration of Triton X-100 solubilized ${ }^{125}$ I-labelled gonadotropin-receptor complex. When Triton X-100 solubilized plasma membrane extracts containing ${ }^{125}$ I-labelled gonadotropin-receptor complex was chromatographed on Sepha$\operatorname{dex}$ G 200 in the presence of $0.1 \%$ Triton X-100 (Fig. 3A), most of the radioactivity was eluted in the void volume (peak I) and the remainder was distributed between two small included peaks (II and III). On subsequent sucrose density gradient centrifugation, peak I was identified as ${ }^{125}$ I-labelled gonadotropin-receptor complex (results are presented in the next section). Peak II was identified as free ${ }^{125} \mathrm{I}$-labelled gonadotropin, which coincided with free ${ }^{125} \mathrm{I}$ labelled gonadotropin as shown in Fig. 3C. The specificity of the interaction of ${ }^{125}$ I-labelled gonadotropin with plasma membrane is shown in Fig. 3B. Saturation of the hormone binding sites with unlabelled gonadotropin $\left(1 \cdot 10^{-7} \mathrm{M}\right)$ prior to treatment with ${ }^{125}$ I-labelled gonadotropin prevented the association of the labelled hormone with binding proteins which were eluted from the column. In contrast, prior exposure of the membranes to bovine serum albumin

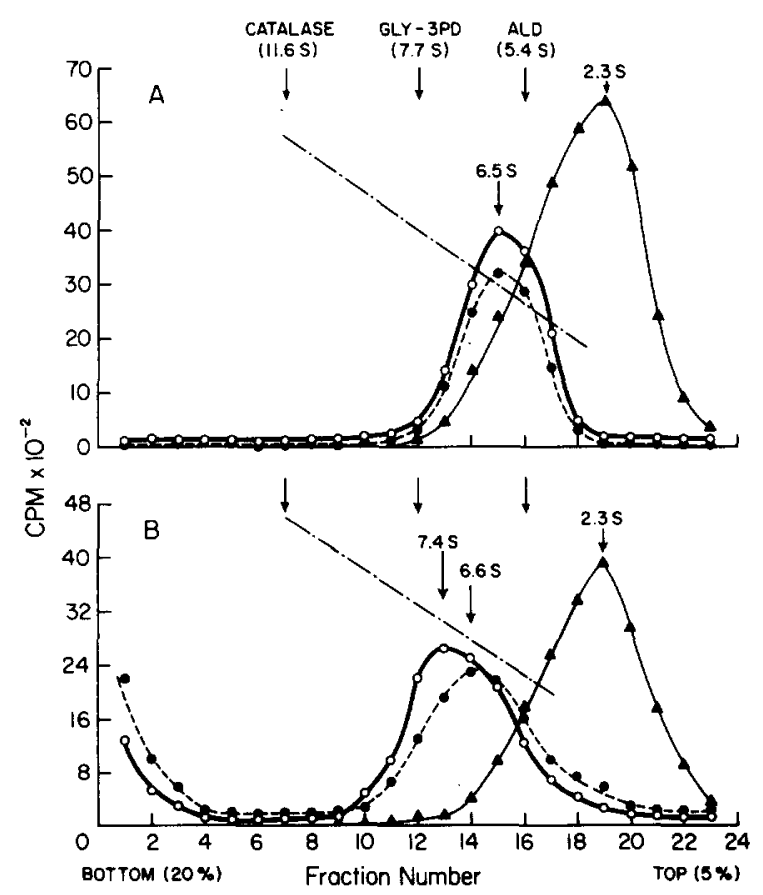

Fig. 4. Sucrose density gradient centrifugation of Triton X-100 solubilized 125 I-labelled gonadotropinreceptor complex. (A) Plasma membrane fractions were prelabelled with ${ }^{125}$ I-labelled gonadotropin and then hormone receptor complex was extracted with $0.4 \%$ Triton X-100 in Buffer A (100 mM Tris-HCl pH 7.2 containing $1 \mathrm{mM} \mathrm{CaCl}{ }_{2}$ and $0.1 \%$ bovine serum albumin). An aliquot (200 $\left.\mu 1\right)$ was then applied on 5-20\% sucrose gradient $(5 \mathrm{ml}$ ) made up in Buffer A containing 0.1\% Triton X-100. The centrifugation was carried out at $38000 \mathrm{rev} . / \mathrm{min}$ in $\mathrm{SW} 50.1$ rotor for $16 \mathrm{~h}$. Five-drop $(230 \mu \mathrm{l})$ fractions were collected and radioactivity was determined in each fraction. (B) Experimental details were the same as in $A$ except gradient did not contain $0.1 \%$ Triton X-100. $\longrightarrow$, fraction I plasma membrane; $0 \longrightarrow 0$, fraction II plasma membrane; $\leadsto \longrightarrow$, Free 125 I-labelled gonadotropin. 
showed no effect upon the subsequent binding and elution of ${ }^{125}$ I-labelled gonadotropin-receptor complex.

Sucrose density gradient centrifugation of detergent solubilized ${ }^{125}$ I-labelled gonadotropin-receptor complex. Aliquots of Triton X-100 solubilized ${ }^{125} \mathrm{I}$ labelled gonadotropin-receptor complex from plasma membrane fractions I and II were also subjected to sucrose density gradient centrifugation in the presence of detergent. The mean sedimentation coefficient of hormone-receptor complex was found to be $6.5 \mathrm{~S}$ for both plasma membrane fractions (Fig. 4A). When sucrose density gradient centrifugations were carried out in the absence of Triton X-100, the hormone receptor complex transformed into an aggregate with rapidly sedimenting peaks. Under such experimental conditions the apparent sedimentation coefficients of hormone receptor complex was found to be $6.6 \mathrm{~S}$ and $7.4 \mathrm{~S}$ for plasma membrane fractions I and II, respectively (Fig. 4B).

Sucrose density gradient centrifugation of solubilized gonadotropin receptor. The sedimentation behavior of the detergent solubilized gonadotropin receptor from two plasma membrane fractions are presented in Fig. 5. Like ${ }^{125}$ I-labelled gonadotropin-receptor complex, free receptors from both membrane fractions also exhibited identical sedimentation coefficients (5.1 S). Similarly, aggregation of free receptor was also observed when the preparations were centrifuged

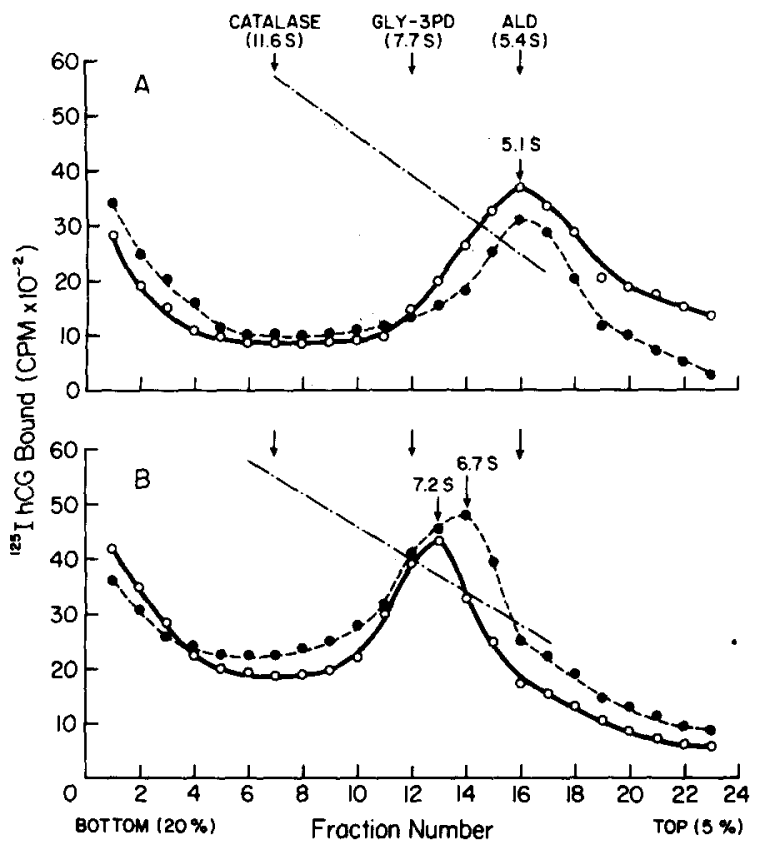

Fig. 5. Sucrose density gradient centrifugation of ${ }^{125}$ I-labelled gonadotropin binding activity of detergent solubilized plasma membrane. (A) Plasma membranes were extracted with $0.4 \%$ Triton X-100 in Buffer A for $1 \mathrm{~h}$ at $4^{\circ} \mathrm{C}$. The clear supernatant after centrifugation was then applied $(200 \mu 1)$ on $5-20 \%$ sucrose gradients (in Buffer A) containing 0.1\% Triton X-100 and centrifugation was carried out at 39000 rev./ min for $16 \mathrm{~h}$. Five drop tractions were collected and $125 \mathrm{I}$-labelled gonadotropin binding was carried out in each fraction by polyethylene glycol precipitation. (B) Experimental details were the same as in $A$ except gradient did not contain Triton X-100. $\rightarrow$, fraction I plasma membrane; 0 0 , fraction II plasma membrane; $4 \longrightarrow$, Free ${ }^{125}$ I-labelled gonadotropin. 
in the absence of Triton X-100 (Fig. 5B). In the absence of the detergent, free receptor from plasma membrane fractions I and II sedimented as single peaks with sedimentation coefficients of $6.7 \mathrm{~S}$ and $7.2 \mathrm{~S}$, respectively. These results are indicative of the possibility that one molecule of gonadotropin might bind to one molecule of the receptor. The increased sedimentation coefficient of free receptor or hormone receptor complex observed in the absence of Triton $\mathrm{X}-100$ could be due to aggregation of proteins following the removal of detergent. At the same time, we cannot rule out the possibility that the removal of detergent may also result in the removal of phospholipids which may be required to maintain the structural integrity of solubilized receptor or the hormone receptor complex.

Modification of gonadotropin binding activity with phospholipases. Since bovine corpus lutheum plasma membranes have been found to contain relatively higher proportions of phospholipid [8] the effect of phospholipases were tested on ${ }^{125}$ I-labelled gonadotropin binding to membranes. Treatment of plasma membranes with phospholipase $\mathrm{A}$ or phospholipase $\mathrm{C}$ inhibited the binding of ${ }^{125}$ I-labelled gonadotropin in a dose dependent manner while treatment with phospholipase $\mathrm{D}$ had no effect. The concentration of phospholipase $\mathrm{A}$ and $\mathrm{C}$ that resulted in $50 \%$ inhibition was between $1.4 \mathrm{mI} . \mathrm{U}$. and $0.6 \mathrm{ml}$.U., respectively. The exposure of the labelled plasma membranes to phospholipases A and C prior to Triton X-100 treatment, did not relase sig-

\section{TABLE II}

SEDIMENTATION PROFILE OF GONADOTROPIN RECEPTOR AND 125 I-LABELLED GONADOTROPINRECEPTOR COMPLEX FROM BOVINE CORPUS LUTEUM PLASMA MEMBRANES UNDER DIFFERENT EXPERIMENTAL CONDITIONS

\begin{tabular}{|c|c|c|}
\hline \multirow[t]{2}{*}{ Condition } & \multicolumn{2}{|c|}{ Sedimentation coefficient (S) } \\
\hline & $\begin{array}{l}\text { With Triton } \\
\mathrm{X}-100 \\
(0.1 \%)\end{array}$ & $\begin{array}{l}\text { Without Triton } \\
\mathrm{x}-100\end{array}$ \\
\hline $\begin{array}{l}125 \text { I-labelled gonadotropin-receptor complex } \\
\text { fraction I } \\
125 \text { I-labelled gonadotropin-receptor complex }\end{array}$ & 6.5 & 6.6 \\
\hline fraction II & 6.5 & 7.4 \\
\hline Free receptor fraction I & 5.1 & 6.7 \\
\hline Free receptor fraction II & 5.1 & 7.2 \\
\hline $\begin{array}{l}\text { Free } 125 \text { I-labelled gonadotropin } \\
125 \text { I-labelled gonadotropin-receptor complex } \\
\text { from fraction I membranes pretreated with }\end{array}$ & 2.3 & 2.3 \\
\hline $\begin{array}{l}\text { phospholipase C } \\
125 \text { I-labelled gonadotropin-receptor complex } \\
\text { from fraction I membranes treated with } \\
\text { phospholipase C after } 125 \text { I-labelled gonado- }\end{array}$ & 6.5 & - \\
\hline $\begin{array}{l}125 \text { I-labelled gonad otropin-receptor complex } \\
\text { from fraction I membranes pretreated with } \\
\text { phospholipase A } \\
125 \text { I-labelled gonadotropin-receptor complex } \\
\text { trom fraction I membranes treated with } \\
\text { phospholipase A after }{ }^{125} \text { I-labelled gonado- } \\
\text { tropin binding }\end{array}$ & 6.5 & - \\
\hline
\end{tabular}


nificant amounts of radioactivity into the medium nor did it affect the sedimentation profile on sucrose density gradient centrifugation. Similarly, pretreatment of plasma membranes with phospholipase $\mathrm{A}$ and $\mathrm{C}$, followed by ${ }^{125} \mathrm{I}$ labelled gonadotropin binding and subsequent solubilization by Triton $\mathrm{X}-100$ showed no effect on the apparent sedimentation coefficient of ${ }^{125}$ I-labelled gonadotropin-receptor complex when compared to untreated plasma membranes. Identical results were obtained with either plasma membrane fraction I or II. A summary of sedimentation profile of gonadotropin receptor under various experimental conditions is given in Table II.

Susceptibility of gonadotropin binding activity to phospholipases further suggests a role of plasma membrane phospholipids in the interaction between ${ }^{125} \mathrm{I}$-labelled gonadotropin and receptor or receptor activity. The observed inhibitory effects of phospholipase $\mathrm{A}$ and $\mathrm{C}$ are in agreement with the results of Gospodarowicz [8], Lee and Ryan [25], but not with Rao and Saxena [9] and Haour and Saxena [10]. However, commercial preparations of phospholipase $\mathrm{C}$ showed a biphasic effect. Concentrations of phospholipase $\mathrm{C}$ up to 10 milliunits inhibited the binding of ${ }^{125} \mathrm{I}$-labelled gonadotropin, and 1.0 unit and higher concentrations of phospholipase $\mathrm{C}$ was stimulatory. However, upon further purification of phospholipase $C$ from calcium phosphate gel [26,27] the stimulatory activity was not observed. This suggested that the stimulatory effect was due to a contaminating enzyme activity associated with phospholipase C, probably neuraminidase activity [27]. The lack of effect on phospholipase $\mathrm{A}$ or $\mathrm{C}$ on sedimentation profile of solubilized gonadotropin-receptor complex suggests that phospholipids may constitute a small portion of ${ }^{125} \mathrm{I}$ labelled gonadotropin-receptor complex, yet are important in the interaction of hormone with the receptor.

\section{Acknowledgement}

This investigation was supported in part by a NIH grant HD06656.

\section{References}

1 Marsh, J.M. (1970) J. Biol, Chem. 245, 1596-1603

2 Menon, K.M.J. and Kiburz, J. (1974) Biochem. Biophys. Res. Comm. 56, 363-371

3 Savard, K., Marsh, J.M. and Rice, B.F. (1965) Recent Prog. Horm. Res. 21, 385

4 Marsh, J.M., Butcher, R.W., Savard, K. and Sutherland, E.W. (1966) J. Biol. Chem. 241, 5436-5440

5 Koch, Y., Zor, U., Chobsieng, P., Lamprecht, S.A., Pomerantz, S. and Lindner, H.R. (1974) J. Endocrinol. 61, 179-191

6 Kawano, A., Gunaga, K.P. and Menon, K.M.J. (1975) Biochim. Biophys. Acta 385, 88-100

7 Rajaniemi, H.J, and Van-Perttula, T. (1972) Endocrinology 90, 1-9

8 Gospodarowicz, D. (1973) J. Biol. Chem. 248, 5042-5049

9 Rao, Ch.V. and Saxena, B.B. (1973) Biochim. Biophys. Acta 313, 372-389

10 Haour, F. and Saxena, B.B. (1974) J. Biol. Chem. 249, 2195-2205

11 Rao, Ch.V. (1974) J. Biol. Chem, 249, 2864-2872

12 Dufau, M.L., Charreau, E.H., Ryan, D. and Catt, K.J. (1974) FEBS Lett. 39, 149-153

13 Lee, Ch.Y. and Ryan, R.J. (1973) Biochemistry 12, 4609-4615

14 Azhar, S. and Menon, K.M.J. (1975) Eur. J. Biochem. 55, 487-495

15 Azhar, S. and Menon, K.M.J. (1975) Biochem. J. 151, 23-36

16 Azhar, S. and Menon, K.M.J. (1975) Eux. J. Biochem., in the Press

17 Solyom, A. and Trams, E.G. (1972) Enzyme (Basel) 13, 329 372

18 Phillips, A.H. and Langdon, R.G. (1962) J. Biol. Chem. 237, 2652-2660 
19 Veeger, C., Der Vartanian, D.V, and Zelyemaker, W.P. (1969) Methods in Enzymology 13, 81-90

20 Langdon, R.G. (1966) Methods in Enzymology 9, 126-137

21 Dufau, M.L., Charreau, E.H. and Catt, K.J. (1973) J. Biol. Chem. 248, 6973-6982

22 Martin, R.G. and Ames, B.N. (1961) J. Biol. Chem. 236, 1372-1379

23 Kuczenski, R. (1973) J. Biol. Chem. 248, 5074-5080

24 Lowry, O.H., Rosebrough, N.J., Farr, A.L. and Randall, R.J. (1951) J. Biol. Chem. 193, 265-275

25 Lee, C.Y. and Ryan, R.J. (1972) Proc. Natl. Acad. Sci. U.S. 69, 3520-3523

26 Diner, B.A. (1970) Biochim. Biophys. Acta 198, 514-522

27 Steinberg, J., Masoro, E.J, and Yu, B.P. (1974) J. Lipid Res. 15, 537-543 